\author{
Boom juridisch \\ Postbus 85576 \\ 2508 CG Den Haag \\ T (070) 3307033 \\ E info@bju.nl \\ I www.boomjuridisch.nl
}

\section{EstateTip}

\title{
Wetsvoorstel 34605: koppeling erkenning en gezamenlijk gezag voor ongehuwde en niet-geregistreerde partners
}

Onlangs is in EstateTip Review (2017-03) aandacht besteed aan het rapport 'Kind en ouders in de 21ste eeuw' van de Staatscommissie Herijking ouderschap. Vandaag richten we ons op een verwant thema: het (ouderlijk) gezag van ongehuwde ouders.

Zoals bekend: wanneer ongehuwde en niet als partner geregistreerde 'levensgezellen' een kind krijgen, is de vrouw uit wie het kind geboren is van rechtswege ouder, artikel 1:198 lid 1 aanhef en onder a BW. Om ouder te worden, moet de andere partner het kind erkennen of adopteren, dan wel moet van die partner het ouderschap gerechtelijk worden vastgesteld, artikel 1:198 lid 1 aanhef en onder $\mathrm{c}$, $\mathrm{d}$, en e respectievelijk artikel 1:199 aanhef en onder c, d en e BW. In de regel wordt gekozen voor de 'eenvoudigste' van die drie: erkenning. Dat kan bij een akte van erkenning plaatsvinden, opgemaakt door de ambtenaar van de burgerlijke stand of bij notariële akte, artikel 1:203 lid 1 BW.

Bij veel ongehuwde partners leeft de gedachte dat zodra de andere partner juridisch ouder is (geworden), deze mede met het gezag over het kind is belast. Niet (breed) bekend bij het publiek is dat voor dit laatste een afzonderlijke handeling nodig is, te weten het op verzoek van beide ouders laten aantekenen in het gezagsregister van artikel 1:244 BW dat zij het gezag over hun minderjarige kinderen gezamenlijk uitoefenen. Laat men dit na, dan oefent als hoofdregel alleen de moeder het gezag over het kind uit.

Op zich vloeit uit dit (eenhoofdig) gezag bij de moeder niet direct bloed voort. Problemen doen zich, onder meer, pas voor op vanuit planningsperspectief relevante momenten als overlijden, (feitelijke) scheiding en vertrek/verhuizing naar het buitenland. Het overlijden van de moeder met eenhoofdig gezag kan een (tijdelijk en ongewenst) gezagsvacuüm tot gevolg hebben. Een eventuele voogdijregeling gemaakt door de overleden moeder zet de andere ouder, in ieder geval vooralsnog, wellicht buiten spel. En ten slotte, een scheiding van de ongehuwde ouders/partners kan extra gecompliceerd worden als deze (onnodig) 'bezwaard' wordt met procedures over het ouderlijk gezag. Het kan kortom geen kwaad om als planner oog te hebben voor ontwikkelingen op het gebied van het gezagsrecht. 
En daarmee zijn we bij het thema van vandaag: het in november vorig jaar ingediende 'Voorstel van wet van de leden Bergkamp en Van Wijngaarden tot wijziging van Boek 1 van het Burgerlijk Wetboek in verband met directe koppeling van erkenning en gezamenlijk gezag voor ongehuwde en niet-geregistreerde partners', (Kamerstukken II 2016/17, 34605).

Doel van het voorstel is, mede, om het bestaande onderscheid met betrekking tot de uitoefening van gezag tussen (kinderen geboren uit) gehuwde ouders en ongehuwde ouders weg te nemen. Het wetsvoorstel voorziet in een systeem dat als hoofdregel inhoudt dat als het ouderschap van de 'andere' ongehuwde partner door erkenning tot stand komt, die ongehuwden van rechtswege gezamenlijk het gezag uitoefenen.

De kern van de regeling treffen we aan in het eerste lid van het nieuw voorgestelde artikel 1:253b BW:

'1. Een persoon die op grond van artikel 203, eerste lid, onder a, een minderjarig kind erkent, oefent van rechtswege gezamenlijk met de moeder het gezag uit over dit kind vanaf het tijdstip van die erkenning, tenzij [...]:

a. één of beide ouders onbevoegd is tot het gezag;

b. het gezag van één van beide ouders is beëindigd en de andere ouder het gezag uitoefent;

c. een voogd met het gezag over het kind is belast;

d. de voorziening in het gezag over het kind is komen te ontbreken;

e. de ouder die het gezag heeft, dit gezamenlijk met een ander dan een ouder uitoefent;

f. de moeder en de erkenner gezamenlijk door overlegging van een daartoe strekkende notariële akte of ten overstaan van de ambtenaar van de burgerlijke stand verklaren dat het gezag alleen door de moeder wordt uitgeoefend [...].' (Curs. FH)

Omdat de erkenning meestal geschiedt bij een door de ambtenaar van de burgerlijke stand opgemaakte akte, krijgt deze de taak om vast te stellen of een van de onder a tot en met $f$ genoemde feiten zich voordoet. Er ontstaat dan geen gezamenlijk gezag van rechtswege. Onder omstandigheden, denk bijvoorbeeld aan een geboorte in het buitenland, kan het zo zijn dat de ambtenaar er niet zeker van is dat géén van de belemmeringsgronden speelt. Ook dan ontstaat door de erkenning geen gezamenlijk gezag van rechtswege.

Uiteraard is ook voorzien dat de beide ouders niet gezamenlijk het gezag willen uitoefenen. Ten slotte kan de rechtbank op gezamenlijk verzoek, of op verzoek van één van hen, het gezamenlijk gezag beëindigen, artikel 1:253n lid 1 eerste volzin BW (nieuw).

Speciale aandacht verdient ook het feit dat een erkenning werkt vanaf het tijdstip waarop zij is gedaan, artikel 1:203 lid 2 BW. Dit geldt ook voor de erkenning die geschiedt bij notariële akte. In theorie zou het van rechtswege ontstaan van gezamenlijk gezag vanaf de notariële erkenning onwenselijke gevolgen kunnen hebben. Er staat immers nog niet vast of een van de belemmeringsgronden speelt. Daarom bepaalt artikel 1:253b lid 3 BW (nieuw) dat het gezamenlijk gezag niet ontstaat bij de notariële akte van erkenning, maar (pas) vanaf het tijdstip dat de ambtenaar van de burgerlijke stand heeft vastgesteld dat geen van die gronden van toepassing is. 
Ook nieuw is dat, om uitreisperikelen en Schiphol-discussies te voorkomen, de moeder die van rechtswege alleen het gezag uitoefent, de rechtbank kan verzoeken om aantekening van dit feit in het gezagsregister, artikel 1:253ba lid $1 \mathrm{BW}$ (nieuw).

Tot slot nog dit. De voorgestelde regeling is niet alomvattend. Als de familierechtelijke betrekking met (juridisch ouderschap van) de andere ongehuwde partner tot stand komt door gerechtelijk vaststelling of eenouderadoptie, ontstaat het gezamenlijk gezag niet van rechtswege. In die situaties moet nog steeds worden teruggevallen op de oude vertrouwde aantekening op beider verzoek in het gezagsregister, artikel 1:252 lid $1 \mathrm{BW}$.

Tot volgende week!

Mr. F.M.H. Hoens 